\title{
RATE OF GROWTH IN RELATION TO BIRTH RANK
}

\section{AND FAMILY SIZE}

\author{
BY \\ M. W. GRANT \\ Formerly of the Applied Nutrition Unit, London School of Hygiene and Tropical Medicine
}

Considerable attention has been given recently to the fact that average heights and weights for age tend to decrease as family size increases. As birth weights increase with parity up to the seventh or eighth child (McKeown and Gibson, 1951), it might have been expected that the average heights and weights of children in large families would be greater, rather than less, than those of only children, but the reverse seems to be the case. What has not yet been elucidated is whether all children in the large families show retarded growth or if some are more handicapped than others. Although Lowe and Gibson (1953) showed that later-born children had fallen behind the average for first-borns by their 3rd birthday, their group of first-borns were of necessity still either only children or the first of two, and the effect on the older children of subsequent additions to a family is not apparent from their study nor from that of Douglas and Blomfield (1958) reporting on the National Child Health Survey.

Scott $(1961,1962)$ has analysed the material available from the London County Council records of heights and weights of school children measured in 1959, but this is cross-sectional data and no information was obtained about birth rank or about the rate of growth of the children concerned; moreover, a failure to record older sibs who had already left school must have resulted in a fair proportion of children being classified into smaller families than those to which they actually belonged.

The present paper deals with long-term (9 years) growth records of individual children, members of London families re-housed on a London County Council estate in Hertfordshire. This study was part of a wider sociological investigation undertaken by the Department of Public Health at the London School of Hygiene and Tropical Medicine. Papers describing the population on the estate and other aspects of the work have already been published by other members of the staff (Brotherston and Chave, 1956; Jefferys, Brotherston and Cartwright, 1960; McDonald, 1957; Martin, Brotherston and Chave, 1957).

\section{Collection of Data}

In May, 1960, all children attending the two secondary modern schools on the estate were asked to fill in forms, giving the name, age, and date of birth of all their brothers and sisters. A total of 1,310 forms was returned, representing 1,061 families; two, or sometimes three, children from the same family were at school together in some instances. Table I shows the distribution by family size.

TABLE I

NUMBER OF FAMILIES OF DIFFERENT SIZE WITH CHILDREN IN THE TWO SECONDARY MODERN SCHOOLS

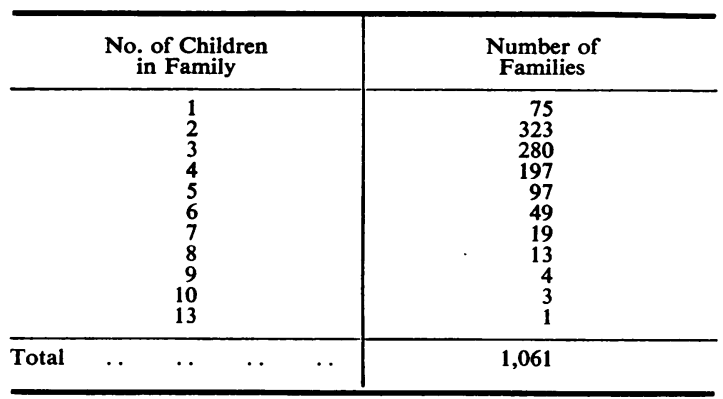

Growth records had not been kept for all the children who filled in these family record forms but the numbers available for analysis were increased by the fact that partial records had been made for older brothers and sisters before they left school, and had also been started for younger sibs still in the primary and junior schools. These made it possible to compare the growth of consecutive children within many of the families. 
Recording the height and weight of all children attending schools on the estate began in February, 1953, and for the first few years measurements were made three times a year-in February, May, and November. Subsequently the February recording was dropped (at the request of the schools) and only the May and November ones continued. This was quite satisfactory as it gave two readings a year at exactly 6-monthly intervals and the main purpose of the growth study was to investigate long-term individual growth patterns.

\section{Analysis by Family Size}

Each child had a record card on which the measurements were graphed as obtained and this ensured that any deviation from the normal rate of growth was quickly and easily detected. It also made it possible to assign intermediate values at any particular age with a reasonable degree of accuracy as the individual record cards were large $\left(9^{\prime \prime} \times 13^{\prime \prime}\right)$ and, within the age period studied, increments were remarkably steady in all but a few exceptional cases. (This will be the subject of a separate paper.) Values pertaining to exact anniversaries of birth have been used for the purposes of the following analyses, so that comparisons between small groups were not distorted by differences in mean age. A straightforward analysis by family size was first made and gave the results set out in Table II (opposite).

The differences found are very similar to those reported by Scott for London children, and the same lessening of the gap between the older girls is apparent, presumably due to the taller ones (from the smaller families) attaining puberty first and thus slowing down their growth while the others were still making normal, or enhanced, gains (Grant and Wadsworth, 1959).

\section{ANALYSIS BY BIRTH RANK}

The same records were then used for an analysis of the mean heights and weights of sub-groups based on birth rank. The results are set out in Table III.

It seems quite clear from this series that the smaller size of children in large families is common to all of them and that the first-born does not achieve the height and weight attained by first-borns who remain only children. Whether they had the potential to do so, or represent a different genetic grouping, is not known.

The data in Table III are less satisfactory for a comparison by birth rank within a given-sized family, as the numbers in the sub-groups are small and the individuals composing them belong to different families. A study of the records of children belonging to the same family often shows a distinct "family pattern" of growth and physique, and this could obscure birth rank differences when small subgroups are made up of individuals drawn from different families and not confined to consecutive children from a fixed group.

MEAN HEIGHT AND WEIGHT, BY BIRTH

\begin{tabular}{|c|c|c|c|c|c|c|c|c|c|c|c|c|c|c|c|c|}
\hline \multirow{3}{*}{\multicolumn{2}{|c|}{$\begin{array}{l}\text { No. of Children } \\
\text { in } \\
\text { Family }\end{array}$}} & \multicolumn{14}{|c|}{ BOYS } & $\frac{\overrightarrow{7}}{0}$ \\
\hline & & \multicolumn{5}{|c|}{ Height (cm.) } & \multicolumn{5}{|c|}{ Weight (kg.) } & \multicolumn{5}{|c|}{ No. in Group } \\
\hline & & 1 st & 2nd & 3 rd & 4th & $\begin{array}{l}\text { 5th } \\
\text { and } \\
\text { Over }\end{array}$ & 1 st & 2nd & 3 rd & 4th & $\begin{array}{l}\text { 5th } \\
\text { and } \\
\text { Over }\end{array}$ & 1 st & 2nd & 3 rd & 4th & $\begin{array}{l}5 \text { की } \\
\text { and } \\
\text { Ong }\end{array}$ \\
\hline $\begin{array}{l}\text { at 6th } \\
\text { Birthday }\end{array}$ & $\begin{array}{c}1 \\
2 \\
3 \\
4 \\
5 \text { and More }\end{array}$ & $\begin{array}{l}114.8 \\
114.0 \\
115.6 \\
111.0 \\
111.8\end{array}$ & $\begin{array}{l}1 \overline{115 \cdot 2} \\
114 \cdot 6 \\
113 \cdot 5 \\
112 \cdot 6\end{array}$ & $\begin{array}{l}\overline{-} \\
1 \overline{112} \cdot 5 \\
113 \cdot 5 \\
112 \cdot 1\end{array}$ & $\frac{\bar{Z}}{1 \overline{13 \cdot 1}}$ & $\begin{array}{l}\bar{z} \\
\overline{111 \cdot 5}\end{array}$ & $\begin{array}{l}21 \cdot 0 \\
20 \cdot 9 \\
22 \cdot 3 \\
20 \cdot 1 \\
19 \cdot 6\end{array}$ & $\begin{array}{l}\overline{21 \cdot 4} \\
21 \cdot 3 \\
21 \cdot 2 \\
20 \cdot 2\end{array}$ & $\begin{array}{l}\overline{-} \\
20 \cdot 5 \\
20 \cdot 9 \\
20 \cdot 5\end{array}$ & $\begin{array}{c}\bar{Z} \\
2 \overline{20 \cdot 3} \\
19 \cdot 7\end{array}$ & $\begin{array}{l}\bar{z} \\
20 \cdot 2\end{array}$ & $\begin{array}{l}17 \\
48 \\
29 \\
13 \\
12\end{array}$ & $\begin{array}{l}\overline{75} \\
54 \\
31 \\
24\end{array}$ & $\begin{array}{l}\overline{7} \\
50 \\
37 \\
28\end{array}$ & $\begin{array}{l}\bar{Z} \\
\overline{34} \\
34\end{array}$ & 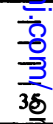 \\
\hline $\begin{array}{l}\text { at 10th } \\
\text { Birthday }\end{array}$ & $\begin{array}{c}1 \\
2 \\
3 \\
4 \\
5 \text { and More }\end{array}$ & $\begin{array}{l}137.5 \\
136 \cdot 8 \\
136 \cdot 6 \\
136.1 \\
134.5\end{array}$ & $\begin{array}{l}\overline{137.8} \\
137.0 \\
135.0 \\
134.6\end{array}$ & $\begin{array}{c}\overline{7} \\
135 \cdot 4 \\
135 \cdot 4 \\
134 \cdot 2\end{array}$ & $\begin{array}{l}\bar{Z} \\
1 \overline{135 \cdot 3} \\
133 \cdot 3\end{array}$ & $\begin{array}{l}\bar{z} \\
\overline{134 \cdot 1}\end{array}$ & $\begin{array}{l}32 \cdot 8 \\
32 \cdot 7 \\
32 \cdot 1 \\
31 \cdot 5 \\
29 \cdot 9\end{array}$ & $\begin{array}{l}\overline{33 \cdot 1} \\
32 \cdot 0 \\
30 \cdot 6 \\
30 \cdot 3\end{array}$ & $\begin{array}{l}\overline{7} \\
3 \overline{31 \cdot 2} \\
30 \cdot 7 \\
30 \cdot 1\end{array}$ & $\begin{array}{c}\bar{Z} \\
3 \overline{1} \cdot 2 \\
29 \cdot 9\end{array}$ & $\begin{array}{l}\bar{z} \\
\overline{30 \cdot 6}\end{array}$ & $\begin{array}{l}40 \\
96 \\
63 \\
30 \\
32\end{array}$ & $\begin{array}{l}\overline{85} \\
73 \\
42 \\
34 \\
\end{array}$ & $\begin{array}{l}\overline{7} \\
55 \\
34 \\
35\end{array}$ & $\begin{array}{l}\bar{z} \\
\overline{36} \\
32\end{array}$ & 吾 \\
\hline $\begin{array}{l}\text { at 12th } \\
\text { Birthday }\end{array}$ & $\begin{array}{c}1 \\
2 \\
3 \\
4 \\
5 \text { and More }\end{array}$ & $\begin{array}{l}147 \cdot 9 \\
146 \cdot 7 \\
146 \cdot 1 \\
145 \cdot 6 \\
144 \cdot 6\end{array}$ & $\begin{array}{l}\overline{148 \cdot 3} \\
146 \cdot 5 \\
144 \cdot 7 \\
143 \cdot 7\end{array}$ & $\begin{array}{l}\overline{-} \\
1 \overline{45} \cdot 0 \\
145 \cdot 4 \\
143 \cdot 0\end{array}$ & $\begin{array}{l}\bar{Z} \\
\overline{144 \cdot 8} \\
142 \cdot 9\end{array}$ & $\begin{array}{l}\bar{z} \\
\overline{144 \cdot 2}\end{array}$ & $\begin{array}{l}39 \cdot 5 \\
39 \cdot 1 \\
38 \cdot 5 \\
37 \cdot 8 \\
35 \cdot 4\end{array}$ & $\begin{array}{l}\overline{40 \cdot 2} \\
37 \cdot 9 \\
36 \cdot 1 \\
35 \cdot 8\end{array}$ & $\begin{array}{l}\overline{-} \\
37 \cdot 6 \\
37 \cdot 6 \\
34 \cdot 7\end{array}$ & $\bar{z}$ & $\begin{array}{l}\bar{Z} \\
37 \cdot 4\end{array}$ & $\begin{array}{r}38 \\
109 \\
69 \\
34 \\
37\end{array}$ & $\begin{array}{l}\overline{83} \\
68 \\
47 \\
40\end{array}$ & $\begin{array}{l}\overline{-} \\
58 \\
39 \\
33\end{array}$ & $\begin{array}{l}\bar{z} \\
\overline{33}\end{array}$ & $\begin{array}{l}\text { To } \\
\text { 梽 } \\
36\end{array}$ \\
\hline $\begin{array}{l}\text { at 14th } \\
\text { Birthday }\end{array}$ & $\begin{array}{c}1 \\
2 \\
3 \\
4 \\
5 \text { and More }\end{array}$ & $\begin{array}{l}160 \cdot 1 \\
159 \cdot 1 \\
158 \cdot 2 \\
158 \cdot 3 \\
158 \cdot 9\end{array}$ & $\begin{array}{l}1 \overline{161 \cdot 7} \\
158 \cdot 8 \\
156 \cdot 8 \\
156 \cdot 0\end{array}$ & $\begin{array}{l}\overline{-} \\
159 \cdot 5 \\
158 \cdot 2 \\
154 \cdot 4\end{array}$ & $\begin{array}{c}\bar{z} \\
\overline{159 \cdot 3} \\
155 \cdot 2\end{array}$ & $\begin{array}{l}\bar{Z} \\
\overline{156 \cdot 9}\end{array}$ & $\begin{array}{l}49 \cdot 0 \\
49 \cdot 3 \\
47 \cdot 4 \\
47 \cdot 2 \\
46 \cdot 6\end{array}$ & $\begin{array}{l}5 \overline{11 \cdot 6} \\
48 \cdot 2 \\
45 \cdot 5 \\
46 \cdot 6\end{array}$ & $\begin{array}{l}\overline{-} \\
49 \cdot 5 \\
46 \cdot 5 \\
44 \cdot 2\end{array}$ & $\begin{array}{l}\bar{Z} \\
49 \cdot 0 \\
44 \cdot 5\end{array}$ & $\begin{array}{l}\bar{z} \\
4 \overline{6} \cdot 2\end{array}$ & $\begin{array}{l}34 \\
88 \\
61 \\
29 \\
28\end{array}$ & $\begin{array}{l}-58 \\
49 \\
39 \\
27\end{array}$ & $\begin{array}{l}\overline{7} \\
37 \\
28 \\
26\end{array}$ & $\begin{array}{l}\bar{Z} \\
\overline{20} \\
22\end{array}$ & $\begin{array}{l}\frac{0}{6} \\
\frac{80}{24} \\
\frac{10}{24}\end{array}$ \\
\hline
\end{tabular}


TABLE II

MEAN HEIGHT AND WEIGHT FOR AGE OF CHILDREN IN DIFFERENT-SIZED FAMILIES

\begin{tabular}{|c|c|c|c|c|c|c|c|c|c|}
\hline \multirow{3}{*}{$\begin{array}{l}\text { Particulars } \\
\text { obtained }\end{array}$} & \multirow{3}{*}{$\begin{array}{c}\text { No. of Children } \\
\text { in Family }\end{array}$} & \multicolumn{8}{|c|}{ Age (yrs) } \\
\hline & & \multicolumn{4}{|c|}{ Boys } & \multicolumn{4}{|c|}{ Girls } \\
\hline & & 6 & 10 & 12 & 14 & 6 & 10 & 12 & 14 \\
\hline $\begin{array}{l}\text { No. of } \\
\text { Records }\end{array}$ & $\begin{array}{c}1 \\
2 \\
3 \\
4 \\
4\end{array}$ & $\begin{array}{l}17 \\
123 \\
133 \\
115 \\
123\end{array}$ & $\begin{array}{r}40 \\
181 \\
191 \\
142 \\
169\end{array}$ & $\begin{array}{r}38 \\
192 \\
195 \\
153 \\
176\end{array}$ & $\begin{array}{r}34 \\
146 \\
147 \\
116 \\
127\end{array}$ & $\begin{array}{r}13 \\
106 \\
111 \\
89 \\
92\end{array}$ & $\begin{array}{r}23 \\
155 \\
169 \\
122 \\
122\end{array}$ & $\begin{array}{r}25 \\
168 \\
182 \\
136 \\
135\end{array}$ & $\begin{array}{l}18 \\
127 \\
151 \\
190 \\
115\end{array}$ \\
\hline $\begin{array}{l}\text { Mean } \\
\text { Height } \\
\text { (cm.) }\end{array}$ & $\begin{array}{c}1 \\
2 \\
3 \\
4 \\
5 \text { or More }\end{array}$ & $\begin{array}{l}114 \cdot 8 \\
114 \cdot 6 \\
114 \cdot 1 \\
112 \cdot 8 \\
111 \cdot 9\end{array}$ & $\begin{array}{l}137 \cdot 5 \\
137 \cdot 3 \\
136 \cdot 3 \\
135 \cdot 5 \\
134 \cdot 1\end{array}$ & $\begin{array}{l}147 \cdot 9 \\
147 \cdot 5 \\
145 \cdot 9 \\
145 \cdot 1 \\
143 \cdot 7\end{array}$ & $\begin{array}{l}160 \cdot 1 \\
160 \cdot 4 \\
158 \cdot 8 \\
158 \cdot 2 \\
156 \cdot 3\end{array}$ & $\begin{array}{l}115 \cdot 6 \\
114 \cdot 5 \\
113 \cdot 8 \\
112 \cdot 8 \\
111 \cdot 9\end{array}$ & $\begin{array}{l}137 \cdot 6 \\
136 \cdot 6 \\
136 \cdot 5 \\
133 \cdot 7 \\
134 \cdot 0\end{array}$ & $\begin{array}{l}150 \cdot 3 \\
149 \cdot 1 \\
148 \cdot 9 \\
145 \cdot 6 \\
145 \cdot 8\end{array}$ & $\begin{array}{l}158 \cdot 1 \\
158 \cdot 6 \\
158 \cdot 8 \\
156 \cdot 2 \\
156 \cdot 8\end{array}$ \\
\hline $\begin{array}{c}\text { Mean } \\
\text { Weight } \\
\text { (kg.) }\end{array}$ & $\begin{array}{l}1 \\
2 \\
3 \\
4 \\
5 \text { or More }\end{array}$ & $\begin{array}{l}21 \cdot 0 \\
21 \cdot 2 \\
21 \cdot 4 \\
20 \cdot 6 \\
20 \cdot 0\end{array}$ & $\begin{array}{l}32 \cdot 8 \\
32 \cdot 9 \\
31 \cdot 8 \\
31 \cdot 0 \\
30 \cdot 2\end{array}$ & $\begin{array}{l}39 \cdot 5 \\
39 \cdot 7 \\
37 \cdot 0 \\
36 \cdot 9 \\
35 \cdot 7\end{array}$ & $\begin{array}{l}49 \cdot 0 \\
50 \cdot 5 \\
48 \cdot 4 \\
47 \cdot 1 \\
45 \cdot 6\end{array}$ & $\begin{array}{l}22 \cdot 3 \\
21 \cdot 3 \\
20 \cdot 8 \\
20 \cdot 5 \\
20 \cdot 0\end{array}$ & $\begin{array}{l}33 \cdot 8 \\
32 \cdot 3 \\
32 \cdot 3 \\
29 \cdot 6 \\
30 \cdot 0\end{array}$ & $\begin{array}{l}43 \cdot 4 \\
40 \cdot 7 \\
40 \cdot 4 \\
36 \cdot 8 \\
37 \cdot 9\end{array}$ & $\begin{array}{l}50 \cdot 8 \\
51 \cdot 0 \\
50 \cdot 3 \\
47 \cdot 9 \\
48 \cdot 9\end{array}$ \\
\hline
\end{tabular}

A difficulty in making direct comparisons within a fixed group of families, however, is the presence of both boys and girls and the fact that it is rare to have records of all the children in a large family at the same age. An attempt was made to overcome these difficulties in the following way:

(1) Instead of using the actual height of the children concerned, a plus or minus "developmental level" (DL) was assigned, being the difference in centimetres between the child's recorded height and the average height at that age, using London 1949 data as the standard for comparison.* Thus a DL value of +3 indicates that the child was $3 \mathrm{~cm}$. taller than the average for his age, and one of -2 that he was $2 \mathrm{~cm}$. shorter than the average. In this way it was possible to use all existing records for children in the same family, without the need to consider boys and girls separately.

* The most recent London data available when the growth recording began.

III

RANK, AND FAMILY SIZE, AND SEX

\begin{tabular}{|c|c|c|c|c|c|c|c|c|c|c|c|c|c|c|}
\hline \multicolumn{15}{|c|}{ GIRLS } \\
\hline \multicolumn{5}{|c|}{ Height (cm.) } & \multicolumn{5}{|c|}{ Weight (kg.) } & \multicolumn{5}{|c|}{ No. in Group } \\
\hline $1 \mathrm{st}$ & 2nd & 3rd & 4th & $\begin{array}{l}\text { 5th } \\
\text { and } \\
\text { Over }\end{array}$ & $1 \mathrm{st}$ & 2nd & 3 rd & 4 th & $\begin{array}{l}\text { 5th } \\
\text { and } \\
\text { Over }\end{array}$ & $1 \mathrm{st}$ & 2nd & 3 rd & 4th & $\begin{array}{c}\text { 5th } \\
\text { and } \\
\text { Over }\end{array}$ \\
\hline $\begin{array}{l}115.6 \\
113.9 \\
115.0 \\
116.1 \\
111.3\end{array}$ & $\begin{array}{r}1 \overline{15} \cdot 0 \\
112.0 \\
111.3 \\
111.5\end{array}$ & $\begin{array}{l}\overline{-} \\
11 \overline{4} \cdot 3 \\
111.7 \\
113.7\end{array}$ & $\begin{array}{c}\bar{Z} \\
\overline{112} \cdot 1 \\
112 \cdot 2\end{array}$ & $\begin{array}{c}\bar{z} \\
\overline{1} \overline{0} \cdot 6\end{array}$ & $\begin{array}{l}22 \cdot 3 \\
20 \cdot 3 \\
21 \cdot 3 \\
22 \cdot 0 \\
19 \cdot 9\end{array}$ & $\begin{array}{l}\overline{22 \cdot 2} \\
20 \cdot 2 \\
20 \cdot 7 \\
19 \cdot 7\end{array}$ & $\begin{array}{l}\overline{-} \\
2 \overline{11 \cdot 0} \\
19 \cdot 8 \\
20 \cdot 7\end{array}$ & $\begin{array}{l}\bar{Z} \\
19 \cdot 6 \\
20 \cdot 1\end{array}$ & $\begin{array}{l}\bar{Z} \\
\overline{19 \cdot 6}\end{array}$ & $\begin{array}{r}13 \\
45 \\
28 \\
14 \\
6\end{array}$ & $\begin{array}{l}\overline{61} \\
39 \\
22 \\
23\end{array}$ & $\begin{array}{l}\overline{-} \\
\overline{44} \\
27 \\
23\end{array}$ & $\begin{array}{l}\bar{z} \\
\overline{26} \\
18\end{array}$ & $\begin{array}{l}\bar{z} \\
\overline{22}\end{array}$ \\
\hline $\begin{array}{l}137.6 \\
135.9 \\
136.2 \\
134.6 \\
132.4\end{array}$ & $\begin{array}{l}1 \overline{137 \cdot 2} \\
135 \cdot 7 \\
132 \cdot 3 \\
134 \cdot 2\end{array}$ & $\begin{array}{c}\overline{-} \\
137 \cdot 7 \\
133 \cdot 2 \\
135 \cdot 4\end{array}$ & $\begin{array}{c}\bar{Z} \\
\overline{134 \cdot 5} \\
134 \cdot 3\end{array}$ & $\begin{array}{c}\bar{Z} \\
\overline{133 \cdot 8}\end{array}$ & $\begin{array}{l}33 \cdot 8 \\
31 \cdot 2 \\
31 \cdot 5 \\
30 \cdot 5 \\
28 \cdot 3\end{array}$ & $\begin{array}{l}\overline{33 \cdot 4} \\
31 \cdot 9 \\
28 \cdot 2 \\
30 \cdot 1\end{array}$ & $\begin{array}{c}\overline{7} \\
33 \cdot 4 \\
29 \cdot 4 \\
30 \cdot 7\end{array}$ & 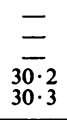 & $\begin{array}{l}\bar{z} \\
\overline{30 \cdot 5}\end{array}$ & $\begin{array}{l}23 \\
77 \\
60 \\
28 \\
19\end{array}$ & $\begin{array}{l}\overline{78} \\
63 \\
30 \\
28\end{array}$ & $\begin{array}{l}\overline{ } \\
46 \\
41 \\
24\end{array}$ & $\begin{array}{l}\overline{-} \\
\overline{23} \\
24\end{array}$ & $\begin{array}{l}\bar{z} \\
\overline{27}\end{array}$ \\
\hline $\begin{array}{l}150 \cdot 3 \\
148 \cdot 2 \\
148 \cdot 8 \\
146 \cdot 4 \\
144 \cdot 9\end{array}$ & $\begin{array}{r}\overline{149 \cdot 9} \\
147 \cdot 1 \\
144 \cdot 7 \\
144 \cdot 8\end{array}$ & $\begin{array}{c}\overline{-} \\
1 \overline{50.8} \\
146.0 \\
147.2\end{array}$ & $\begin{array}{c}\bar{Z} \\
\overline{145 \cdot 4} \\
147 \cdot 0\end{array}$ & $\begin{array}{c}\bar{Z} \\
\overline{146 \cdot 3}\end{array}$ & $\begin{array}{l}43 \cdot 4 \\
39 \cdot 2 \\
38 \cdot 9 \\
37 \cdot 6 \\
36 \cdot 2\end{array}$ & $\begin{array}{l}-\overline{42 \cdot 2} \\
39 \cdot 8 \\
35 \cdot 2 \\
36 \cdot 1\end{array}$ & $\begin{array}{c}\overline{7} \\
42 \cdot 4 \\
37 \cdot 0 \\
38 \cdot 7\end{array}$ & $\begin{array}{c}\bar{Z} \\
\begin{array}{c}37 \cdot 6 \\
39 \cdot 6\end{array}\end{array}$ & $\begin{array}{l}\bar{Z} \\
\overline{39 \cdot 2}\end{array}$ & $\begin{array}{l}25 \\
82 \\
66 \\
40 \\
29\end{array}$ & $\begin{array}{l}\overline{86} \\
76 \\
35 \\
28\end{array}$ & $\begin{array}{l}\overline{-} \\
40 \\
40 \\
25\end{array}$ & $\begin{array}{l}二 \\
\overline{21} \\
25\end{array}$ & $\begin{array}{l}\bar{Z} \\
\overline{28}\end{array}$ \\
\hline $\begin{array}{l}158.1 \\
158.6 \\
159.2 \\
157.4 \\
156.6\end{array}$ & $\begin{array}{l}\overline{158.7} \\
157.1 \\
155.0 \\
155.6\end{array}$ & $\begin{array}{c}\overline{\bar{T}} \\
1 \overline{160 \cdot 2} \\
157.5 \\
158.6\end{array}$ & $\begin{array}{c}\bar{Z} \\
\overline{154 \cdot 8} \\
156 \cdot 0\end{array}$ & $\begin{array}{c}\bar{Z} \\
\overline{157 \cdot 3}\end{array}$ & $\begin{array}{l}50 \cdot 8 \\
49 \cdot 5 \\
48 \cdot 5 \\
46 \cdot 9 \\
47 \cdot 5\end{array}$ & $\begin{array}{l}5 \overline{52 \cdot 4} \\
50 \cdot 2 \\
44 \cdot 8 \\
47 \cdot 0\end{array}$ & $\begin{array}{l}\overline{7} \\
52 \cdot 1 \\
48 \cdot 0 \\
50 \cdot 1\end{array}$ & $\begin{array}{l}\bar{Z} \\
5 \overline{51 \cdot 9} \\
50 \cdot 7\end{array}$ & $\begin{array}{c}\bar{Z} \\
\overline{49 \cdot 0}\end{array}$ & $\begin{array}{l}18 \\
63 \\
54 \\
38 \\
27\end{array}$ & $\begin{array}{l}\overline{64} \\
65 \\
31 \\
24\end{array}$ & $\begin{array}{l}\overline{-} \\
32 \\
34 \\
21\end{array}$ & $\begin{array}{r}\bar{Z} \\
\frac{6}{23}\end{array}$ & $\begin{array}{l}\bar{z} \\
\overline{20}\end{array}$ \\
\hline
\end{tabular}

RANK 
(2) In the larger families records had not been obtained for all the children, but many consecutive pairs and a smaller number of consecutive threes were available. Individual DL values were read at exactly the same age for each pair of children within a family, the age chosen being as near to 8 years as possible, never under 6 nor over 11 , and always within a period where the record extended a full year on either side. The comparison was confined to the younger age group so as to avoid complications due to differing ages of pubertal growth effects and also so as to include children who subsequently went to grammar schools or other schools off the estate after age 11 and were then lost to the survey. Records for twins and triplets were not used.

The results, set out in Table IV, show that, in eight of the ten groups considered, the later-born child of any consecutive pair within a family tended to be taller than the immediately preceding one. The only exceptions are the negligible difference $(-0.06$ $\mathrm{cm}$.) between the third and fourth child in the fourchild family, and the difference $(-0.33 \mathrm{~cm}$.) between the fourth and fifth child in the largest families. In this last case, the fifth child was not the last in eighteen of the 33 families but had younger sibs

TABLE IV

DEVELOPMENTAL LEVELS, AT THE SAME AGE, OF CONSECUTIVE CHILDREN IN FAMILIES OF DIFFERENT SIZE

\begin{tabular}{|c|c|c|c|c|}
\hline $\begin{array}{l}\text { No. of } \\
\text { Children } \\
\text { in Family }\end{array}$ & $\begin{array}{l}\text { Birth } \\
\text { Ranks }\end{array}$ & $\begin{array}{c}\text { Number } \\
\text { of } \\
\text { Pairs }\end{array}$ & $\begin{array}{c}\text { Develop- } \\
\text { mental } \\
\text { Levels }\end{array}$ & $\begin{array}{c}\text { Dif- } \\
\text { ference }\end{array}$ \\
\hline 2 & 1st and 2 nd & 103 & $\begin{array}{r}1 s t+1 \cdot 61 \\
2 n d+2 \cdot 98\end{array}$ & $+1 \cdot 37$ \\
\hline \multirow[t]{2}{*}{3} & 1st and 2 nd & 106 & $\begin{array}{r}1 s t+0 \cdot 89 \\
2 n d+1 \cdot 35\end{array}$ & +0.46 \\
\hline & 2nd and 3 rd & 79 & $\begin{array}{l}2 \mathrm{nd}+0 \cdot 06 \\
3 \mathrm{rd}+2 \cdot 26\end{array}$ & $+2 \cdot 20$ \\
\hline \multirow[t]{3}{*}{4} & 1st and 2nd & 55 & $\begin{array}{r}1 \mathrm{st}+0.20 \\
2 \mathrm{nd}+0.56\end{array}$ & +0.36 \\
\hline & 2nd and $3 \mathrm{rd}$ & 63 & $\begin{array}{r}2 \mathrm{nd}-0.32 \\
3 \mathrm{rd}+0.46\end{array}$ & +0.78 \\
\hline & 3 rd and 4th & 49 & $\begin{array}{l}3 \mathrm{rd}+0.59 \\
4 \mathrm{th}+0.53\end{array}$ & -0.06 \\
\hline \multirow[t]{4}{*}{5 or More } & 1 st and 2nd & 44 & $\begin{array}{r}1 \mathrm{st}-0.32 \\
2 \mathrm{nd}-0.18\end{array}$ & $+0 \cdot 14$ \\
\hline & 2nd and 3 rd & 49 & $\begin{array}{r}2 \mathrm{nd}+0 \cdot 10 \\
3 \mathrm{rd}+0 \cdot 51\end{array}$ & +0.41 \\
\hline & 3rd and 4th & 40 & $\begin{array}{l}3 \text { rd }-0 \cdot 22 \\
\text { 4th }+0 \cdot 55\end{array}$ & +0.77 \\
\hline & 4th and 5 th $^{*}$ & 33 & $\begin{array}{l}4 \text { th }+0.06 \\
5 \text { th }-0.27\end{array}$ & -0.33 \\
\hline
\end{tabular}

* The fifth child in eighteen of these families was not the last but had younger sibs following on. following on. The numbers of records were too small, however, to make any further breakdown worthwhile.

The difference between the means for the second and third child in the three-child family is statistically significant, the standard error of the difference being 0.97 , and that between the children in the two-child family approaches significance (S.E. 0.80). Despite the small differences, however, the trend seems clear and suggests that the established correlation between birth weight and birth rank also holds good for height and birth rank within the age range 7 to 10 years.

Lowe and Gibson (1953) reported finding a slight negative association between birth order and rate of growth, the correlation being -0.17 for males and -0.22 for females. This, however, is not necessarily inconsistent with the present findings because of the different nature of the material analysed. They based their statement on an analysis of weight at the 3rd birthday of 1,782 children who had been born in Birmingham during 1947 and about whom various records had been made at that time. Most of these children (at age 3) would still have been the youngest or second youngest in their respective families, and the group of "first-born" would include all those destined to be only children (i.e. those who, despite a lower birth weight, show, as school children, the greatest mean values for height and weight related to age).

These findings, taken together with the present data, suggest that the advent of each additional child to a family, acts as a check to the growth of all preceding sibs, and it becomes desirable to find out whether the slower building up of the body is due to a deficiency in the building material (food) being provided, or to other influences (e.g. emotional or infectious) exercising an inhibitory effect on the utilization of nutrients.

Young babies in larger families often suffer from frequent colds and minor infections, usually said to be "brought home from school" by some of the older children. This, however, can hardly account for the slower growth in the two-child families and might, in any case, be expected to affect the second baby rather than the first. Nor is it likely (at least not in the present group) that poverty prohibited an adequate diet in these small families; and, here again, one might expect the second child to be more adversely affected than the first if that were the cause. It is interesting that it should be the first child whose growth falls so far behind that which is achieved by the only child, and while the eldest of a family may have responsibilities thrust upon them while still very young, the retardation in growth is evident at an 
age before assistance with household chores etc. could have reached major proportions.

\section{Possible Effect of BirTh Spacing}

One point that needs to be considered is the amount of attention that can be given to the first baby when a second follows close on its heels. Weaning is a period when a child is often difficult about its food and a mother with only one infant to care for tends to expend much time and patience coaxing it to finish its meals and trying to tempt it with various new foods. When there is more than one child demanding attention, the same time cannot be spared for each individual unless there is adequate help from other adults or conscientious adolescents. If there is a new baby before the preceding one is able to look after itself at meal times, the older one is likely to receive much less attention than an only child, while the new baby, being the more obviously helpless, receives the greater amount of care.

The figures set out in Table $\mathrm{V}$ lend some support to this view, though the differences are not statistically significant.

TABLE V

MEAN HEIGHT AT 6th BIRTHDAY RELATED TO SPACE BETWEEN BIRTHS

\begin{tabular}{c|c|c|c}
\hline \multicolumn{2}{c|}{ No. of Children in Family } & \multicolumn{1}{c}{ Mean Height (cm.) } \\
\cline { 3 - 4 } 2 & $\begin{array}{l}\text { Mean for all "first of two" } \\
\text { Mean for 1st when 2nd follows } \\
\text { within 2 years }\end{array}$ & 114.0 & 113.9 \\
\hline & $\begin{array}{l}\text { Mean for all "first of three" } \\
\text { Mean for 1st when 2nd follows } \\
\text { within 2 years }\end{array}$ & $115 \cdot 6$ & 113.1 \\
\hline $\begin{array}{l}\text { Mean for all "second of three" } \\
\text { Mean for 2nd when 3rd } \\
\text { follows within 2 years }\end{array}$ & 114.6 & 115.0 \\
\hline
\end{tabular}

In connexion with birth spacing, it was interesting to find that the birth of a girl was, on average, followed by a second birth more quickly that that of a boy. Whether this is physiological or represents a greater feeling of satisfaction on the part of the parents when a boy has been produced is not known. Table VI shows the findings in this respect.

In the larger families the issue is confused, as many of them were started before the war, suffered an interruption during the war years, were started up again in 1946 or 1947 , and then show another gap before being re-housed. Several families that gave the appearance of having been completed produced new additions after settling in on the new estate
TABLE VI

SPACE BETWEEN BIRTHS RELATED TO SEX OF THE OLDER CHILD

\begin{tabular}{|c|c|c|c|c|}
\hline \multicolumn{2}{|c|}{$\begin{array}{l}\text { No. of Children } \\
\text { in Family }\end{array}$} & $\begin{array}{l}\text { Sex of } \\
\text { Older Child }\end{array}$ & $\begin{array}{l}\text { Years before } \\
\text { Next Birth }\end{array}$ & $\begin{array}{c}\text { Number of } \\
\text { Records }\end{array}$ \\
\hline \multicolumn{2}{|c|}{2} & $\begin{array}{l}\text { Male } \\
\text { Female }\end{array}$ & $\begin{array}{l}4 \cdot 01 \\
3.43\end{array}$ & $\begin{array}{r}103 \\
86\end{array}$ \\
\hline \multirow{2}{*}{3} & 1 st and 2 nd & $\begin{array}{l}\text { Male } \\
\text { Female }\end{array}$ & $\begin{array}{l}2 \cdot 93 \\
2 \cdot 33\end{array}$ & $\begin{array}{l}79 \\
70\end{array}$ \\
\hline & 2nd and $3 \mathrm{rd}$ & $\begin{array}{l}\text { Male } \\
\text { Female }\end{array}$ & $\begin{array}{l}5 \cdot 10 \\
4 \cdot 07\end{array}$ & $\begin{array}{l}86 \\
82\end{array}$ \\
\hline 4 & 1 st and 2 nd & $\begin{array}{l}\text { Male } \\
\text { Female }\end{array}$ & $\begin{array}{l}3 \cdot 12 \\
3 \cdot 01\end{array}$ & $\begin{array}{l}81 \\
88\end{array}$ \\
\hline
\end{tabular}

and even in the group of 174 four-child families, the youngest child was 16 to 25 years younger than the eldest in nineteen cases.

\section{Height Gains of Junior School Children Related to Family Size}

Having regard to the present data and those published by other workers already referred to, it seems clear that the larger the family the slower the rate of growth of all the children in it, and the effect of this is established by the age of 6 years or perhaps even earlier if births follow closely together. It remains to be considered whether the children in larger families fall still further behind during their later growth period. Table VII shows the height gained between the 6th and the 10th birthday by the children in the present study.

TABLE VII

GAIN IN HEIGHT BETWEEN 6th AND 10th BIRTHDAYS, BY FAMILY SIZE

\begin{tabular}{|c|c|c|c|c|}
\hline \multirow{2}{*}{$\begin{array}{l}\text { No. of } \\
\text { Children } \\
\text { in Family }\end{array}$} & \multicolumn{2}{|c|}{$\begin{array}{l}\text { Height Gain between 6th } \\
\text { and 10th Birthdays }(\mathrm{cm} .)\end{array}$} & \multicolumn{2}{|c|}{ Number of Records } \\
\hline & Boys & Girls & Boys & Girls \\
\hline 1 & $23 \cdot 3$ & $23 \cdot 6$ & 17 & 13 \\
\hline 2 & $23 \cdot 0$ & $23 \cdot 4$ & 98 & 88 \\
\hline 3 & $22 \cdot 9$ & $23 \cdot 3$ & 95 & 89 \\
\hline 4 & $22 \cdot 4$ & $22 \cdot 1$ & 76 & 67 \\
\hline 5 or More & $22 \cdot 1$ & $22 \cdot 6$ & 85 & 63 \\
\hline
\end{tabular}

Only a few of the differences between the means are statistically significant, but taken together with the previous Tables the general trend seems quite definite. The differences and their standard errors are set out in Table VIII (overleaf).

As in the comparison of attained height and weight for age, these records were broken down by birth rank as well as by family size. Despite the fact that 
TABLE VIII

SIGNIFICANCE OF THE DIFFERENCES IN HEIGHT GAINS, BY FAMILY SIZE

\begin{tabular}{|c|c|c|c|c|}
\hline \multirow{2}{*}{$\begin{array}{c}\text { No. of } \\
\text { Children } \\
\text { in Family } \\
\text { Compared }\end{array}$} & \multicolumn{2}{|l|}{ Boys } & \multicolumn{2}{|c|}{ Girls } \\
\hline & $\begin{array}{c}\text { Difference } \\
\text { between Means }\end{array}$ & $\begin{array}{c}\text { S.E. of } \\
\text { Difference }\end{array}$ & $\begin{array}{c}\text { Difference } \\
\text { between Means }\end{array}$ & $\begin{array}{l}\text { S.E. of } \\
\text { Difference }\end{array}$ \\
\hline $\begin{array}{l}1 \text { and } 2 \\
1 \text { and } 3 \\
1 \text { and } 4 \\
1 \text { and } 5\end{array}$ & $\begin{array}{l}0.32 \\
0.34 \\
0.84 \\
1.23 \\
\end{array}$ & $\begin{array}{l}0.53 \\
0.53 \\
0.53 \\
0.52 \\
\end{array}$ & $\begin{array}{l}0 \cdot 26 \\
0 \cdot 35 \\
1.51 \\
1.02 \\
\end{array}$ & $\begin{array}{l}0.70 \\
0.68 \\
0.70 \\
0.69 \\
\end{array}$ \\
\hline $\begin{array}{l}2 \text { and } 3 \\
2 \text { and } 4 \\
2 \text { and } 5\end{array}$ & $\begin{array}{l}0.02 \\
0.52 \\
0.91\end{array}$ & $\begin{array}{l}0.31 \\
0.31 \\
0 \cdot 30\end{array}$ & $\begin{array}{l}0.09 \\
1.25 \\
0.76\end{array}$ & $\begin{array}{l}0.42 \\
0.45 \\
0.44\end{array}$ \\
\hline $\begin{array}{l}3 \text { and } 4 \\
3 \text { and } 5\end{array}$ & $\begin{array}{l}0.50 \\
0.89\end{array}$ & $\begin{array}{l}0.31 \\
0 \cdot 30\end{array}$ & $\begin{array}{l}1 \cdot 16 \\
0.67\end{array}$ & $\begin{array}{l}0.42 \\
0.41\end{array}$ \\
\hline 4 and 5 & $0 \cdot 39$ & $0 \cdot 30$ & 0.49 & 0.44 \\
\hline
\end{tabular}

the numbers in the sub-groups so obtained are very small, the overall picture is remarkably similar to that provided by Table III. The actual figures are given in Table IX.

Although birth rank differences are here inconclusive, two things seem clear: that the slower rate of growth of children in large families persists into their school years, and that the presence of younger brothers and sisters prevents the first-born from growing at the rate shown by only children. Taking Tables III and IX together, there is a slight suggestion that the last-born is in the most favourable position for growth, and the degree to which the growth of the older sibs is depressed may, to some extent, turn on the length of time for which they remained in this favoured position.

\section{Possible Causes of the Differences in Growth RATES}

(1) DIET.-The first likely explanation that comes to mind to account for the slower growth of children in large families is that of inadequate meals. It is unlikely that, in the population under consideration, a direct shortage of food was the immediate cause. Unlike infants, children between six and 10 years of age are able to feed themselves at meal-times and to say when they are hungry. Nowadays most of them have ample pocket-money with which they buy sweets, ice-cream, potato crisps, etc., at various times during the day and any day of the week. Any who are short on this score have a chance of "fillingup" on school dinners and on school milk unwanted by their friends. It is, however, perfectly possible that the overall nutritional value of the food eaten by children in larger families might be less good than that in smaller families; in particular there might be smaller helpings of the expensive protein-rich foods (meat, fish, eggs, and cheese) and also of the still more expensive, and also more troublesome to prepare, fresh vegetables and fruit. The snacks bought by children for themselves tend to be mainly sugars and fats.

A study of the food consumption of children of comparable age in different-sized families seems to be needed, but it would also be necessary to be able to compare their activities before the results of such a study could be properly interpreted. The annual reports of the National Food Survey Committee (Ministry of Agriculture, Fisheries and Food, 1962, and previous years) are sometimes quoted as showing that large families fail to meet their nutritional requirements, but these reports do not provide satisfactory evidence in this respect for a variety of reasons. For one thing they are not a record of total consumption: they record only "food purchased or otherwise obtained for consumption in the home, or in packed meals taken from home; food eaten outside the household, sweets, soft and alcoholic drinks, fish liver oil, and vitamin supplements are excluded." It is perfectly possible that children in large

TABLE IX

HEIGHT GAIN (cm.) BETWEEN SIXTH AND TENTH BIRTHDAYS, BY BIRTH RANK AND FAMILY SIZE

\begin{tabular}{|c|c|c|c|c|c|c|c|c|c|c|c|}
\hline \multirow{3}{*}{$\begin{array}{l}\text { Particulars } \\
\text { Measured }\end{array}$} & \multirow{3}{*}{$\begin{array}{l}\text { No. of } \\
\text { Children } \\
\text { in } \\
\text { Family }\end{array}$} & \multicolumn{10}{|c|}{ Birth Rank } \\
\hline & & \multicolumn{5}{|c|}{ Boys } & \multicolumn{5}{|c|}{ Girls } \\
\hline & & 1st & 2nd & 3 rd & 4 th & 5th \&c & $1 \mathrm{st}$ & 2nd & 3 rd & 4th & 5th \&c \\
\hline $\begin{array}{l}\text { Height Gain } \\
\text { (cm.) } \\
\text { between } \\
\text { 6th and 10th } \\
\text { Birthdays }\end{array}$ & $\begin{array}{r}1 \\
2 \\
3 \\
4 \\
5 \text { and More } \\
\end{array}$ & $\begin{array}{l}23 \cdot 3 \\
22 \cdot 6 \\
23 \cdot 4 \\
22 \cdot 4 \\
22 \cdot 1\end{array}$ & $\begin{array}{l}2 \overline{23 \cdot 3} \\
22 \cdot 6 \\
22 \cdot 5 \\
22 \cdot 2\end{array}$ & $\begin{array}{l}\overline{7} \\
23 \cdot 0 \\
22 \cdot 5 \\
22 \cdot 3\end{array}$ & $\begin{array}{l}\bar{Z} \\
22 \cdot 4 \\
21 \cdot 4\end{array}$ & $\begin{array}{l}\bar{Z} \\
\overline{22 \cdot 4}\end{array}$ & $\begin{array}{l}23 \cdot 6 \\
23 \cdot 3 \\
22 \cdot 8 \\
22 \cdot 5 \\
20 \cdot 6\end{array}$ & $\begin{array}{l}\overline{23 \cdot 4} \\
23 \cdot 2 \\
21 \cdot 5 \\
22 \cdot 9\end{array}$ & $\begin{array}{l}\overline{7} \\
23 \cdot 8 \\
21 \cdot 5 \\
22 \cdot 5\end{array}$ & $\begin{array}{l}\bar{Z} \\
2 \overline{22} \cdot 9 \\
23 \cdot 3\end{array}$ & $\overline{\bar{z}}$ \\
\hline $\begin{array}{c}\text { No. of } \\
\text { Records }\end{array}$ & $\begin{array}{r}1 \\
2 \\
3 \\
4 \\
5 \text { and More }\end{array}$ & $\begin{array}{l}17 \\
46 \\
26 \\
12 \\
11\end{array}$ & $\begin{array}{l}\overline{52} \\
34 \\
23 \\
18\end{array}$ & $\begin{array}{l}\overline{-} \\
\overline{35} \\
19 \\
16\end{array}$ & $\begin{array}{l}\bar{z} \\
\overline{22} \\
20\end{array}$ & $\begin{array}{l}\bar{Z} \\
\overline{20}\end{array}$ & $\begin{array}{r}13 \\
45 \\
28 \\
13 \\
5\end{array}$ & $\begin{array}{l}\overline{43} \\
31 \\
14 \\
18\end{array}$ & $\begin{array}{l}\overline{-} \\
\overline{30} \\
20 \\
16\end{array}$ & $\begin{array}{l}\bar{z} \\
\overline{20} \\
12\end{array}$ & $\begin{array}{l}\bar{z} \\
\overline{12}\end{array}$ \\
\hline
\end{tabular}


families eat a greater proportion of their food in the form of snacks bought by themselves, just as nurses whose hospital diet was inadequate made up with tea and buns in local cafés (King Edward's Hospital Fund for London, 1943).

A still more serious criticism of the National Food Survey records is that, before the nutritive value of the recorded diet is compared with the estimate of requirements, an entirely arbitrary deduction is made to allow for wastage of edible food, over and above the deductions from purchased weights which allow for normal "preparation waste" and inedible material such as fruit stones, bone in meat, fish, etc. This assumption - that all families of all sizes and all social classes waste 10 per cent. of all their various foods-does not seem to be based on any recorded observations. In reply to an earlier criticism on this point (Grant, 1957), it was stated that it was to allow for unused left-overs and family food fed to domestic pets, as well as mere wanton waste. It means, however, that, if there is less than 10 per cent. waste of edible food in large families, their apparent failure to meet their calorie needs disappears.

During the pre-war surveys made by the Rowett Research Institute (1955) a special investigation was made into waste of this nature in $\mathbf{4 2 0}$ households in various parts of Britain; of these, 290 did not waste any food at all, and in the remainder the wastage was mainly of bread and fats. Expressed in terms of lost calories "the wastage of edible material in the households, much of which was probably plate waste, was of the order of 1 per cent. of the energy available". Allowance must be made for the fact that these surveys were made during a time of severe economic depression, when hunger was common in many areas; it is also possible that the mere fact that wastage of this type was being noted made some families more circumspect during the week of the recording. Nevertheless it is extremely unlikely that a family that is short of food will continually throw away a tenth of all its purchases. In a one-child family, a rejected helping may well be thrown out, but in a large family it is more than likely that one of the other children will finish it up. Moreover the number of cats and dogs kept does not (fortunately) rise in direct proportion to the number of children in a family.

Finally, as recently pointed out by Berry and Hollingsworth (1963), the comparison of the (reduced) calculated intake with a scale of allowances drawn up by the British Medical Association in 1950 "begs the question as to how nearly the recommended allowances correspond to requirements". If the individuals (including the adults) composing the large families are, on the average, small, this alone would reduce their food needs.

(2) INFECTION.-With regard to the alternative possibility that the slower rate of growth might be due to infections acting as brakes on development, Gibson and McKeown (1952), studying morbidity in the first year of life in Birmingham, say that "it seems reasonable to suppose that the increased risk to later births in poor circumstances is due, at least in part, to increased infection conveyed by older siblings". It is not known if the junior school children in the present survey were attacked by infections more frequently if they belonged to a larger family rather than a smaller one. Only one of the several junior schools on the estate made a note on the growth record card when a child had an illness, operation, or accident. Such incidents were often accompanied by temporary failure to gain weight (or even temporary loss of weight) but there was no evident deflexion in the height gains. In this connexion Tanner (1961) states that "minor and relatively short illnesses... cause no discernible retardation of growth rate in the great majority of well-nourished children . . . children with continuous colds, ear disease, sore throats, and skin infections are on average smaller than the others, but the smaller size is not considered to be due to the infections."

On the other hand, Acheson (1960) found that, in children under 5 years of age, illnesses lasting no more than a few weeks involved a loss in expected stature of the order of $1^{\prime \prime}$ in a year's growth, with no evidence of subsequent acceleration, and even illnesses of less degree caused a measurable retardation. A series of very small checks could have occurred without detection in the present survey, the cumulative effect showing as a smooth curve progressing merely at a slightly lesser angle than the average.

(3) REST.-Quite apart from any direct effect of an infection on the physiology of the growth process, there is the probability that children in large families would get less rest and less "feeding-up" during récovery, than only children or those with only one sib. When children must share a bedroom (and sometimes also a bed) unbroken sleep is less easily come by and time which an only child spends resting is more liable to be used for play. The larger the family the less chance for quiet repose.

A report by Stewart (1962), analysing the interests and activities of differently-placed children, suggests that an elder child feels a need to keep in evident advance of his younger sibs and that this stimulates him to greater effort, both mental and physical. The 
report is entitled "The Success of the First-born Child" but this "success" may be achieved at the expense of growth (though this is not necessarily harmful).

(4) Community Trends.-As is well known, the mean height for age of London children has risen markedly in the last 50 years. This rise, however, has slackened in post-war years and the changes between 1954 and 1959 were very small in the younger age groups, two even showing decreases. In the present study all measurements used for the comparison of consecutive children within a family were taken between 1954 and 1958. During this period the mean height for age of junior and infant school children on the estate (approximately 2,750) showed minor fluctuations but no evidence of any tendency to rise. Thus the lesser height of the earlier born children could not be explained on the basis of their belonging to year-of-birth groups with lower averages.

(5) Heredity.--It remains a possibility that parents who produce children genetically destined to grow slowly are also those who produce large families.

Clearly the whole subject is one that deserves further study, but it is not likely to prove easy to disentangle the many factors that may be involved.

Note: No comparison was made of the growth rates of older children as these are complicated by pubertal factors. In boys, for example, there is frequently a slowing down of growth before a pubertal spurt, and a group with a lesser gain in height between, say, 11 and 13 years might in fact be the more advanced physiologically. Similarly, in girls over 12, a group containing a greater number of more mature girls will gain less height than a more immature group, even if the latter are "better" fed.

\section{SUMMARY}

(1) Data from a long-term growth study have been analysed for evidence of the effect of birth rank and family size.

(2) Height gains between the ages of 6 and 10 years were less in large families than in small ones.

(3) There was a tendency for each successive child in a family to be taller (between the ages of 6 and 11) than the preceding sibs.
(4) Despite this, mean height and weight for age decreased as family size increased.

(5) The more children in a family, the further the height of the first-born fell behind that attained by only children of comparable age.

(6) Possible reasons for these trends are discussed.

Thanks are due to the head teachers of the various schools on the estate for their patient co-operation during the 9 years of recording. Without their help this study could not have been made.

\section{REFERENCES}

Acheson, R. M. (1960). In "Human Growth", ed. J. M. Tanner, p. 73. (Symposia of the Society for the Study of Human Biology, vol. 3.), Pergamon Press, Oxford.

Berry, W. T. C., and Hollingsworth, D. F. (1963). Proc, Nutr. Soc., 22, 48.

Brotherston, J. H. F., Chave, S. P. W., and others (1956). Brit. J. prev. soc. Med., 10, 200.

Douglas, J. W. B., and Blomfield, J. M. (1958). "Children under Five". Allen and Unwin, London.

Gibson, J. R., and McKeown, T. (1952). Brit. J. prev. soc. Med., 6, 183.

Grant, M. W. (1957). Nature (Lond.), 180, 587. and Wadsworth, G. R. (1959). Med. Offr, 102, 303

Jefferys, M., Brotherston, J. H. F., and Cartwright, A. (1960). Brit. J. prev. sec. Med., 14, 64.

King Edward's Hospital Fund for London (1943) "Memorandum on Hospital Diet".

Lowe, C. R., and Gibson, J. R. (1953). Brit. J. prev. soc." Med., $7,78$.

McDonald, A. D. (1957). Publ. Hlth, 70, 122.

McKeown, T., and Gibson, J. R. (1951). Brit. J. prev. soc. Med., 5, 98.

Martin, F. M., Brotherston, J. H. F., and Chave, S. P. W. (1957). Ibid., 11, 196.

Ministry of Agriculture, Fisheries, and Food: National Food Survey Committee (1962). "Domestic Food Consumption and Expenditure, 1960". H.M.S.O., London.

Rowett Research Institute (1955). "Family Diet and Health in Pre-war Britain". A report to the Carnegie U.K. Trust.

Scott, J. A. (1961). "Report on the Heights and Weights (and other measurements) of School Pupils in the County of London in 1959". London County Council. (1962). Brit. J. prev. soc. Med., 16, 165.

Stewart, M. (1962). "The Success of the Firstb-orn Child". Workers, Educational Association, London.

Tanner, J. M. (1961). "Education and Physical Growth". University of London Press. 